\title{
Groundwater recharge during spring thaw in the Prairie Pothole Region of North America
}

\author{
Brenton Sharratt \\ USDA Agricultural Research Service, \\ 213 LJ Smith Hall, Washington State University, \\ Pullman, Washington, 99164, USA \\ E-mail: sharratt@wsu.edu
}

\begin{abstract}
Snowmelt governs recharge in the Prairie Pothole Region of North America, but little is known about the soil at the time of recharge. Depth of snow, surface water, water table, and frozen soil were measured within a 2-ha landscape depression in Minnesota during spring thaw in 2000 and 2001. The water table rose by at least $1 \mathrm{~m}$ within $24 \mathrm{~h}$ after a pond formed within the landscape depression as a result of snowmelt. Recharge of groundwater is a seemingly localised process where surface water infiltrates via unfrozen conduits or soil matrix beneath an ephemeral pond within a prairie pothole.
\end{abstract}

Keywords: depression focused recharge; frozen soil; infiltration; macropores; snowmelt; water table.

Reference to this paper should be made as follows: Sharratt, B. (2009) 'Groundwater recharge during spring thaw in the Prairie Pothole Region of North America', Int. J. Water, Vol. 5, No. 2, pp.100-108.

Biographical notes: Brenton Sharratt is a soil scientist with the USDA Agricultural Research Service in Pullman, Washington, USA. His research interest focuses on soil and water conservation and management. The research reported in this paper was undertaken while he was stationed at the North Central Soil Conservation Research Laboratory in Morris, Minnesota, USA.

\section{Introduction}

The prairie pothole is a landscape depression ranging in size from $<0.5$ to several hectares. Potholes are part of the landscape that characterises the Prairie Pothole Region of North America. This region comprising $775,000 \mathrm{~km}^{2}$ in the north central USA and south central Canada was formed during the last glaciation and is considered to be the most important breeding ground for waterfowl in North America (Smith et al., 1964). Prairie potholes are typically isolated watersheds of which $50 \%$ have been drained in the past 50 years to facilitate agricultural operations.

Groundwater can be replenished in the Prairie Pothole Region by depression-focused recharge. Depression-focused recharge is the process whereby runoff (from rain or snowmelt) is channelled to the bottom of landscape depressions. Runoff collected in these depressions can then infiltrate through the soil and enter groundwater aquifers. Snowmelt is an important source for replenishing groundwater in the 
Prairie Pothole Region. During snowmelt, melt water is channelled to the bottom of landscape depressions as a result of frozen soil impeding infiltration. These landscape depressions temporarily fill with water until, in the spring, the soil has thawed sufficiently to allow infiltration. Little is known, however, about the dynamic changes in groundwater below the prairie pothole landscape during snowmelt and spring thaw.

Infiltration of snowmelt in landscape depressions has been found to occur prior to the soil thawing in the spring. Johnsson and Lundin (1991), for example, observed that drainage at a field site in central Sweden began several weeks before the soil completely thawed in spring. Baker and Spaans (1997) also observed drainage from an ephemeral pond while the soil was frozen in Minnesota. Baker and Spaans determined that infiltration approached the saturated hydraulic conductivity of the soil despite a frozen layer $0.2-0.4 \mathrm{~m}$ thick in the soil profile. Both of these studies suggest that infiltration must occur through unfrozen preferential pathways. Recently, Sharratt et al. (1999) found that the water table below a landscape depression in Minnesota rose several metres in the spring while the soil was frozen. They later reported (Sharratt et al., 2000) that the concomitant rise in the water table with an increase in water content throughout a $1.5 \mathrm{~m}$ soil profile beneath an ephemeral pond in a landscape depression during spring thaw could only occur through large unfrozen cracks in the soil profile at the bottom of a landscape depression. Similarly, Derby and Knighton (2001) found that groundwater recharge occurred from ponded snowmelt even though part of the soil profile was frozen beneath a landscape depression in North Dakota. Hayashi et al. (2003) observed rapid infiltration of ponded snowmelt only after the soil profile thawed beneath a landscape depression in Saskatchewan; however, they observed that thaw depth was irregular, with several localised areas of deep thaw penetration, under the ephemeral pond and conceptualised that infiltration is magnified only after thawing of the localised areas within the landscape depression.

This study investigates the timing of groundwater recharge with respect to the depth of soil thawing within a prairie pothole. Of particular interest was identification of the mechanism by which surface water infiltrates seemingly frozen soil to cause a rapid rise in the groundwater table below a landscape depression during spring thaw within the Prairie Pothole Region of North America.

\section{Materials and methods}

This study was conducted near Morris, Minnesota $\left(45^{\circ} \mathrm{N}, 95^{\circ} \mathrm{W}\right)$. Morris lies within the Prairie Pothole Region of North America (Figure 1) and is typified by a continental climate with an annual air temperature of $5^{\circ} \mathrm{C}$ and precipitation of $600 \mathrm{~mm}$ (annual snowfall of $1000 \mathrm{~mm}$ ). Daily mean temperatures are below $0^{\circ} \mathrm{C}$ from October 25 to April 15. The experimental site is located $11 \mathrm{~km} \mathrm{NE}$ of Morris on an upland plateau of the Olivia Till Plain. The plateau is characterised by hummocky terrain with landscape depressions typically encompassing an area of 1-2 ha and having $<2 \mathrm{~m}$ of relief. These depressions were formed by melting of stagnant ice stranded in debris during the last glaciation. 
Figure 1 The prairie pothole region of North America (patterned polygon) and location of Morris, Minnesota (star)

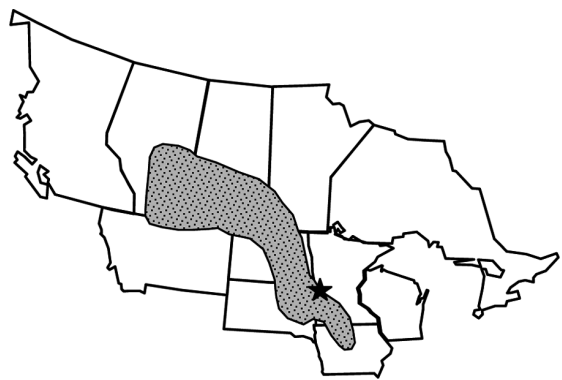

The landscape depression selected for this study was 2 ha in area with about $2 \mathrm{~m}$ of relief; these dimensions are typical of depressions throughout the Prairie Pothole Region of North America (Richardson et al., 1994). The major axis of the depression was oriented NW-SE (Figure 2). Soil types across the depression consist of a poorly-drained Parnell silty clay loam (Typic Argiaquolls) at the bottom of the depression, Hamerly clay loam (Aeric Calciaquolls) on the slopes, and Barnes loam (Udic Haploborolls) in the upland positions. The landscape depression was in fallow (not cropped), but the area surrounding the depression was in corn or soybean.

Figure 2 Topographic map of landscape depression with elevation (m) above mean sea level depicted by contour lines

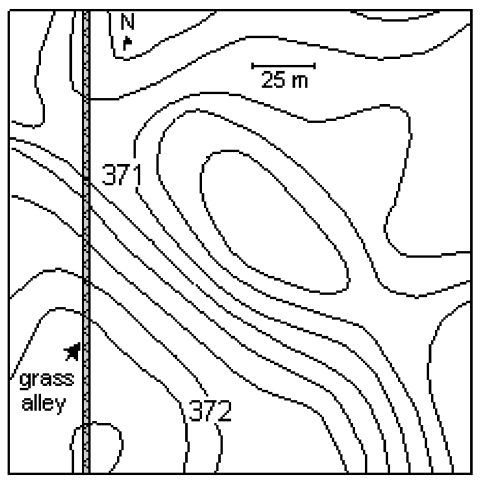

Instrumentation to monitor depth of snow, surface water (ephemeral pond), and water table was installed in January 2000 and March 2001. Depth of snow or surface water in the landscape depression was measured using an ultrasonic transducer positioned at the lowest elevation in the depression and $1.5 \mathrm{~m}$ above the soil surface. Depth of the water table was measured by a pressure transducer located inside a groundwater well; the well was installed at the centre of the depression in 1990. Periodic checks with a ruler or measuring tape of depth of snow, surface water, and water table aided in verifying instrument performance. Air temperature, relative humidity, and precipitation were also measured at the experimental site. All instruments were wired to a data logger that was programmed to monitor sensors every $60 \mathrm{~s}$ and record data hourly.

Thaw depth was measured one day after initial appearance of surface water or the pond in the landscape depression (25 February 2000 and 6 April 2001). Thaw depth was 
measured at ten locations above the perimeter of the pond on the SW and NE slopes by inserting a $2-\mathrm{mm}$ diameter pointed rod into the soil until resistance by a frozen layer prevented further insertion. The maximum depth to which the subsoil was frozen was measured three days after the termination of the experiment by extracting $1.5-\mathrm{m}$ long, 38-mm diameter soil cores taken on the SW slope and above the perimeter of the pond in the landscape depression. The core samples were probed and visually inspected for ice in the soil matrix. In addition, the depth of the frozen soil was measured by frost tubes (Ricard et al., 1976) located on the upland position of the landscape depression. The frost tubes were monitored twice weekly.

Within $24 \mathrm{~h}$ after initiation of groundwater recharge (rise in the water table), the depth to which the soil was thawed beneath the pond (area of $2500 \mathrm{~m}^{2}$ ) was measured by inserting a $1.5-\mathrm{m}$ long, $5-\mathrm{mm}$ diameter pointed rod into the soil. Soil thaw depth beneath the pond was determined at each position on a $0.3 \times 0.2 \mathrm{~m}$ grid pattern; probing was accomplished in about $4 \mathrm{~h}$. The pond was then drained by unplugging the drain tile inlet (the drain tile inlet, which protrudes above the soil surface and carries surface water directly into the subsurface drain tile, was sealed in the autumn of 1999 and 2000 to contain runoff) in the landscape depression.

In 2000, probing beneath the pond revealed several unfrozen conduits that protruded vertically through the frozen soil layer. Soil core samples were extracted from these conduits as well as immediately adjacent to the conduits in May 2000 (after sufficient drying) and analysed for differences in soil structure and texture.

\section{Results and discussion}

The winter (November through March) of 1999-2000 was warmer and drier while the winter of 2000-2001 was colder and wetter than normal. Air temperatures were $4.5^{\circ} \mathrm{C}$ higher and $3.0^{\circ} \mathrm{C}$ lower while total precipitation was $20 \mathrm{~mm}$ lower and $75 \mathrm{~mm}$ higher during the consecutive winters compared with the 30 -year average of $-8.0^{\circ} \mathrm{C}$ and $115 \mathrm{~mm}$. Snowfall totalled $635 \mathrm{~mm}$ and $1390 \mathrm{~mm}$ during consecutive winters, which was $62 \%$ and $136 \%$ of normal. Snow cover in the landscape depression was sparse during the winter of 1999-2000 (maximum snow depth was $160 \mathrm{~mm}$ on 17 February), but remained persistent during the winter of 2000-2001 with a maximum depth of $560 \mathrm{~mm}$ on 13 March 2001. Snow cover rapidly dissipated beginning 22 February 2000 and 31 March 2001 when maximum daily temperatures persistently exceeded $0^{\circ} \mathrm{C}$. Snowmelt was also hastened by a respective 6.1 and $1.5-\mathrm{mm}$ rainfall on 23 February 2000 and 31 March 2001. No precipitation otherwise occurred after these dates and prior to pond formation.

The sequence of observations occurring days before and after pond formation and recharge of groundwater within the landscape depression during the spring of 2000 and 2001 are summarised in Table 1. In 2000, a pond within the landscape depression was not visually apparent at 1500 Central Daylight Time (CDT) on 23 February, but had formed by 07:00 CDT on 24 February. The pond likely formed by 01:00 CDT on 24 February at which time the addition of water to the bottom of the landscape depression by runoff appeared to balance the depletion of snow cover. This is portrayed in Figure 3 where the depth of snow cover decreased until 01:00 CDT on 24 February after which there was a rise in the level of surface water. Likewise, in the spring of 2001, a pond within the landscape depression was not visible at 15:00 CDT on 4 April, but had formed 
by 08:00 CDT on 5 April. The pond likely formed by 23:00 CDT on 4 April when the addition of water to the bottom of the landscape depression by runoff balanced the depletion of snow cover. The depth of snow cover decreased until 23:00 CDT on 4 April after which an increase occurred in the depth of the pond (Figure 4). Snowmelt runoff had accumulated within the landscape depression before the pond was visible; indeed, this was most apparent on 4 April 2001 when water was observed below a layer of snow/slush in the landscape depression.

Figure 3 Depth of snow, surface water or pond, and water table within the landscape depression during spring thaw 2000. Time of day is referenced to events on 24 February as indicated in text (see online version for colours)

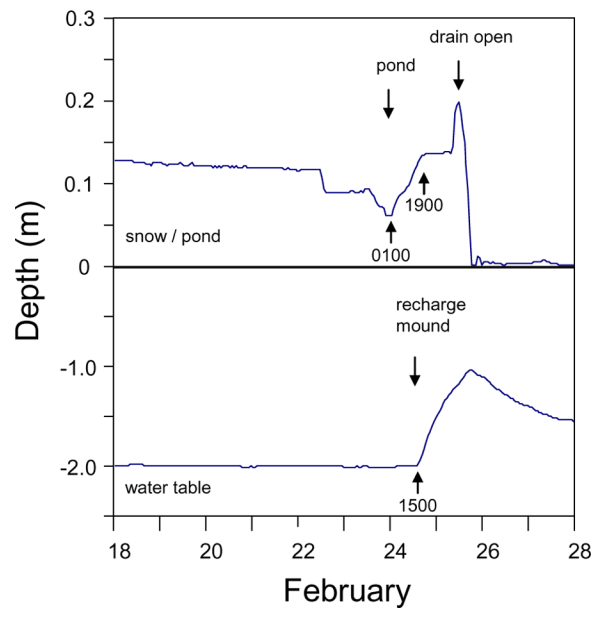

Table 1 Sequence of observations of snow and pond depth, groundwater recharge, and depth of frozen soil within a landscape depression near Morris, MN during the spring of 2000 and 2001

\begin{tabular}{|c|c|c|c|}
\hline Year & Day & Hour & Observations \\
\hline \multirow[t]{15}{*}{2000} & 17 February & 04:00 & Snow depth $(160 \mathrm{~mm})$ reaches \\
\hline & & & Zenith before rapid melt \\
\hline & 23 February & $14: 00$ & Onset of 6.1-mm rainfall event \\
\hline & & $15: 00$ & Pond not visually apparent \\
\hline & 24 February & 01:00 & Snow/pond depth data indicates \\
\hline & & & Possible formation of pond \\
\hline & & 07:00 & Pond visible; no snow cover \\
\hline & & & Within landscape depression \\
\hline & & $15: 00$ & Begin groundwater recharge \\
\hline & & 19:00 & Cessation of lateral water flow \\
\hline & & & Into landscape depression \\
\hline & 25 February & 09:00 & Onset of 14-mm rainfall event; \\
\hline & & & Thawed conduits under pond \\
\hline & & $12: 00$ & Drain tile inlet unplugged; \\
\hline & & & Soil frozen $0.1 \mathrm{~m}$ to $0.9 \mathrm{~m}$ depth \\
\hline
\end{tabular}


Table 1 Sequence of observations of snow and pond depth, groundwater recharge, and depth of frozen soil within a landscape depression near Morris, MN during the spring of 2000 and 2001 (continued)

\begin{tabular}{llll}
\hline Year & Day & Hour & Observations \\
\hline 2001 & 13 March & $08: 00$ & Snow depth $(560 \mathrm{~mm})$ reaches \\
& & Zenith \\
& 18 March & $06: 00$ & Groundwater recharge begins \\
31 March & $01: 00$ & Onset of 1.5 mm rainfall event \\
4 April & $15: 00$ & Pond not visually apparent \\
& $23: 00$ & Snow/pond depth data indicates \\
& & Possible formation of pond \\
& $08: 00$ & Pond visible; no snow cover \\
& & Within landscape depression \\
& & Pond depth at zenith; possible \\
& $23: 00$ & Overflow from depression \\
& & Soil under pond thawed; \\
& $09: 00$ & Soil around perimeter of pond \\
& & Frozen from 0.2 m to 0.9 m depth \\
& & Onset of 72 mm rainfall event \\
& & Drain tile inlet unplugged \\
\hline
\end{tabular}

The rise in the level of the pond after 01:00 CDT on 24 February 2000 and 23:00 CDT on 4 April 2001 resulted from continued snowmelt as well as lateral flow of water along the slopes of the landscape depression. No snow cover was observed within the landscape depression at 07:00 CDT on 24 February 2000 or at 08:00 CDT on 5 April 2001. In the spring of 2000, lateral flow of water appeared to cease by 1900 CDT on 24 February (Figure 3). Thereafter, the depth of the pond remained stable until rain commenced at 09:00 CDT on 25 February. A $14 \mathrm{~mm}$ rainfall resulted in an increase of $60 \mathrm{~mm}$ in the depth of the pond. At the end of the rainfall event (12:00 CDT on 25 February), the drain tile inlet was unplugged to allow surface water in the landscape depression to drain. In the spring of 2001, pond depth remained stable after 23:00 CDT on 5 April 2001 even though $72 \mathrm{~mm}$ of rainfall occurred late on 6 April and into 7 April. Lack of an increase in depth of surface water caused by lateral water flow or rainfall after 5 April was due to overflow of surface water into an adjacent landscape depression. Indeed, overflow of surface water into the adjacent landscape depression is constrained by a $0.35 \mathrm{~m}$ ridge on the SE end of the experimental depression (Figure 1).

Recharge of groundwater commenced at 15:00 CDT on 24 February 2000 (Figure 3). The rise in the water table was initiated approximately $14 \mathrm{~h}$ after pond formation. The water table rose nearly $1 \mathrm{~m}$ within $24 \mathrm{~h}$ after initiation of recharge. In 2001, groundwater recharge began about 06:00 on 18 March 2001 (Figure 4). The rise in the groundwater table was initially very gradual, but was rapid at the time of pond formation (5 April). The gradual rise in the water table between 18 March and 5 April occurred in response to snowmelt events caused by daily maximum air temperatures periodically exceeding $0^{\circ} \mathrm{C}$. 
Figure 4 Depth of snow/pond and water table within the landscape depression during spring 2001. Reference to time pertains to cessation of ponding on 5 April as indicated in text (see online version for colours)

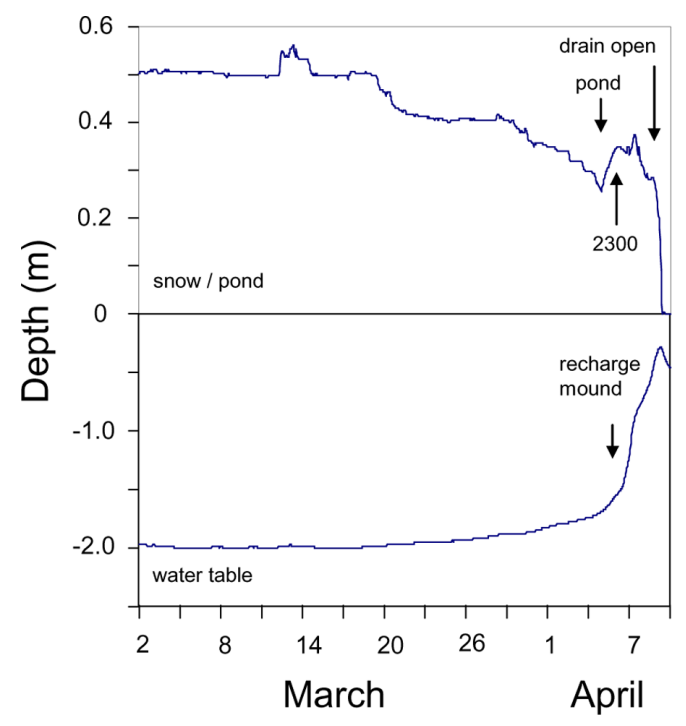

At the time of pond formation and rapid groundwater recharge, the upper part of the soil profile was thawed around the perimeter of the pond. Thaw depth was $0.1 \mathrm{~m}$ $(\mathrm{SE}=5 \mathrm{~mm})$ on 25 February 2000 and, although less uncertain, not more than $0.2 \mathrm{~m}$ on 6 April 2001. While frost tubes indicated a thaw depth of $0.05 \mathrm{~m}$, probing with a pointed-rod indicated a thaw depth of $0.2 \mathrm{~m}(\mathrm{SE}=0.01 \mathrm{~m})$ on 6 April 2001 . This disparity in thaw depth in 2001 is due to differences in instrumentation since the frost tube closely mimics the $0 \mathrm{C}$ isotherm in the soil whereas penetration of a pointed rod is influenced by ice composition and content in the soil profile. Differences in detecting the depth of soil thaw by frost tubes and penetrating rods are magnified under near-isothermal conditions of the soil profile which likely occurred as a result of a thick snowpack in late winter and gradual rise in temperatures during early spring 2001. Soil frost tubes and soil core samples indicated that the soil was frozen at a depth of $0.9 \mathrm{~m}$ $(\mathrm{SE}=0.01 \mathrm{~m})$ both years, thus a frozen soil layer was observed at a depth of $0.1-0.9 \mathrm{~m}$ and $0.2-0.9 \mathrm{~m}$ during groundwater recharge in 2000 and 2001, respectively. Surface water, therefore, appeared to infiltrate and flow through the soil profile to a depth of about $2 \mathrm{~m}$ (depth of water table) despite a frozen layer that was at least $0.7-\mathrm{m}$ thick within the soil profile.

Within $24 \mathrm{~h}$ of commencement of groundwater recharge (25 February 2000 and 6 April 2001), the soil underlying the pond was probed to assess its physical state (thaw depth or the occurrence of unfrozen conduits or pathways in the soil profile) whereby surface water could bypass the $\geq 0.7-\mathrm{m}$ layer of frozen soil. In 2000 , thaw depth beneath the pond was typically $0.1 \mathrm{~m}$. However, 5 thawed conduits were found within a $10 \mathrm{~m}^{2}$ area near the lowest position in the landscape depression. These conduits were large relative to conventional soil macropores with a surface area ranging from about $0.1-0.4 \mathrm{~m}^{2}$. Two of the five conduits were completely thawed through which surface water could bypass the frozen soil layer. Although the remaining three conduits were thawed only to a depth of $0.35-0.6 \mathrm{~m}$ (not completely thawed), no observations 
were made of unfrozen channels or pathways that extended horizontally from the walls of the vertical conduits. The shape of the conduits was either cylindrical or rectangular; the two cylindrical conduits had a diameter of $0.3 \mathrm{~m}$ and $0.5 \mathrm{~m}$ while the three rectangular conduits had a surface area of $0.16 \mathrm{~m}^{2}, 0.3 \mathrm{~m}^{2}$, and $0.38 \mathrm{~m}^{2}$. In 2001 , our observations indicated that the soil profile underlying nearly the entire area of the pond (except the SE end) was completely thawed. The pointed rod could be inserted $>1 \mathrm{~m}$ into the soil profile albeit with some difficulty. This was in contrast to the conditions observed in 2000. Although uncertainty exists as to the cause of the soil profile being completely thawed underneath the pond and not above the perimeter of the pond on 6 April 2001, the possible isothermal soil conditions existing in early spring and additional thermal energy in snowmelt runoff was likely sufficient to thaw the soil profile at the time of groundwater recharge. Nevertheless, our observations suggest that groundwater recharge can occur during and immediately after snowmelt through unfrozen soil or conduits beneath ephemeral ponds in the early spring.

Structural and textural analysis was performed on soil core samples taken from unfrozen conduits and the area immediately adjacent to these conduits in the spring of 2000. No differences were found in either structure or texture. The soil was characterised by granular structure in the upper $0.1 \mathrm{~m}$ of the soil profile and subangular blocky structure from $0.1-\mathrm{m}$ to $0.7-\mathrm{m}$ depth. Textural analysis indicated a clay loam (20-25\% sand and 30-35\% clay) above $0.2 \mathrm{~m}$ and a silty clay loam (15-20\% sand and $30-35 \%$ clay) from $0.2 \mathrm{~m}$ to $1.0 \mathrm{~m}$ depth. Similarities in structure and texture between soils that comprise thawed conduits and the adjacent matrix offer little insight as to the process by which unfrozen conduits are formed beneath ephemeral ponds in landscape depressions during snowmelt and spring thaw. However, extensive cracking of the soil at the bottom of the landscape depression was observed only during the winter of 1999-2000. Indeed, cracks several metres long and as wide as $32 \mathrm{~mm}$ and deep as $270 \mathrm{~mm}$ were measured near the bottom of the landscape depression on 26 January 2000 (Figure 5). Little precipitation prior to soil freezing in the autumn of 1999 (October-November precipitation totalled $10 \mathrm{~mm}$ ) vs. 2000 (October-November precipitation totalled $125 \mathrm{~mm}$ ) may have promoted more extensive cracking during the winter of 1999-2000.

Figure 5 Soil cracks filled with snow as found at the bottom of the landscape depression on 26 January 2000. A metre stick lies across the soil surface for reference (see online version for colours)

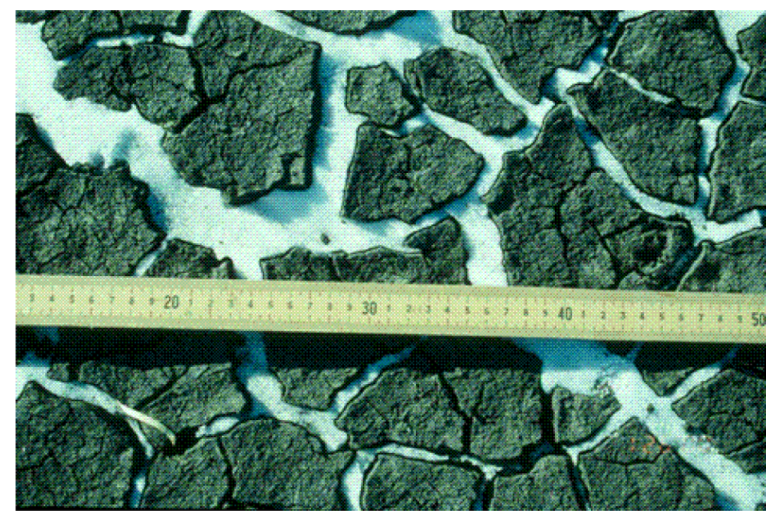




\section{Conclusions}

Groundwater recharge beneath a landscape depression in the Prairie Pothole Region occurred immediately after snowmelt, while the soil profile appeared frozen. During snowmelt, a pond was formed at the bottom of the landscape depression. Recharge occurred as surface water flowed through unfrozen soil or bypassed a frozen soil layer via unfrozen conduits or pathways. These conduits were generally $0.1-0.4 \mathrm{~m}^{2}$ in area and, in some instances, completely thawed. Formation of these conduits may be associated with wide and deep cracks that developed as the soil, which is susceptible to shrinking and swelling, froze during winter. The thermal energy supplied by snowmelt runoff may also play a role in rapidly thawing the soil profile or conduits at the bottom of the landscape depression. Further investigation is warranted in regard to the process by which the soil beneath an ephemeral pond thaws and surface water flows through unfrozen conduits in the soil profile to recharge groundwater during spring thaw in the Prairie Pothole Region of North America.

\section{References}

Baker, J.M. and Spaans, E.J.A. (1997) 'Mechanics of meltwater movement above and within frozen soil', in Iskandar, I.K., Wright, E.A., Radke, J.K., Sharratt, B.S., Groenevelt, P.H. and Hinzman, L.D. (Eds.): International Symposium on Physics, Chemistry, and Ecology of Seasonally Frozen Soils, United States Army CRREL Special Report 97-10, US Army Cold Regions Research and Engineering Laboratory, Hanover, New Hampshire, USA, pp.31-36.

Derby, N.E. and Knighton, R.E. (2001) 'Field-scale preferential transport of water and chloride tracer by depression-focused recharge', Journal of Environmental Quality, Vol. 30, pp.194-199.

Hayashi, M., van der Kamp, G. and Schmidt, R. (2003) 'Focused infiltration of snowmelt water in partially frozen soil under small depressions', Journal of Hydrology, Vol. 270, pp.214-229.

Johnsson, H. and Lundin, L.C. (1991) 'Surface runoff and soil water percolation as affected by snow and soil frost', Journal of Hydrology, Vol. 122, pp.141-159.

Ricard, J.A., Tobiasson, N. and Greatorex, A. (1976) The Field Assembled Frost Gage, Technical Note, Corps of Engineers, United States Army Cold Regions Research and Engineering Laboratory, Hanover, New Hampshire.

Richardson, J.L., Arndt, J.L. and Freeland, J. (1994) 'Wetland soils of the prairie potholes', Advances in Agronomy, Vol. 52, pp.121-171.

Sharratt, B., Benoit, G. and Daniel, J. (2000) 'Groundwater recharge during spring thaw in the prairie pothole region', in Kane, D. (Ed.): Water Resources in Extreme Environments, American Water Resources Association, TPS-99-4, Middleburg, Virginia.

Sharratt, B., Benoit, G., Daniel, J. and Staricka, J. (1999) 'Snow cover, frost depth, and soil water across a prairie pothole landscape', Soil Science, Vol. 164, pp.483-492.

Smith, A.G., Stoudt, J.H. and Gollop, J.B. (1964) 'Prairie potholes and marshes', in Linduska, J.P. (Ed.): Waterfowl Tomorrow, United States Fish and Wildlife Service, Washington, DC. 